\title{
PENERAPAN MODEL PEMBELAJARAN KOOPERATIF TEAM ASSISTED INDIVIDUALIZATION (TAI) UNTUK MENINGKATKAN HASIL BELAJAR PESERTA DIDIK KELAS 8.3 SEMESTER II SMPN 1 SUMENEP TAHUN AJARAN 2015/2016
}

\author{
Sri Hartatik \\ SMPN 1 Sumenep \\ *Corresponding Author: faridmashudi31@gmail.com
}

DOI: 10.24929/lensa.v11i1.127

Received: 22 Desember $2020 \quad$ Revised: 20 Februri $2021 \quad$ Accepted: 01 Maret 2021

\begin{abstract}
ABSTARK
Diakui atau tidak saat ini kebanyakan guru mengajar dikelas lebih banyak menggunakan metode ceramah, alasan yang dikemukakan oleh guru mengapa cenderung menggunakan metode ceramah adalah mudah dilaksanakan, selain itu alasan lainnya adalah kebanyakan murid yang diajarnya bersifat pasif. Namun apakah benar alasan yang dikemukakan oleh guru seperti itu? Menurut hemat penulis, hal tersebut tidak sepenuhnya benar, berdasarkan pengalaman dilapangan sebagai praktisi pendidikan (guru), guru lebih banyak menggunakan metode ceramah dalam mengajar karena mereka miskin metode mengajar yang lain, memang diakui atau tidak Pemerintah sebenarnya telah banyak menggelontorkan uang untuk mendidik dan melatih guru melalui Pendidikan dan pelatihan (Diklat), Workshop, seminar dan lain sebagainya. Tujuannya satu, yaitu meningkatkan pengetahuan dan keterampilan guru di dalam menggunakan metode pembelajaran yang merangsang murid untuk aktif, kreatif dan inovatif. Salah satu metode yang dikenalkan kepada guru adalah Model Pembelajaran Kooperatif dengan menggunakan Tehnik Team Asistead Individualisition (TAI). Secara garis besar tehnik ini dilakukan dengan cara membagi kelas menjadi kelompo kecil sekitar 4 atau lima orang yang dipilih secara heterogen, kemudian diberikan bantuan baik secara individual melalui kelompok. Guru memberikan Lembar Kerja Siswa (LKS), kemudian masing-masing kelompok berdiskusi menemukan konsep yang ada di LKS tersebut, setelah itu, setiap siswa diberikan tanggung jawab untuk memecahkan soal di LKS itu, sehingga disinilah peran aktif setiap anggota kelompok dituntut. Penelitian ini dilaksanakan di SMP Negeri 1 Sumenep kelas 8-3, menggunakan jenis Penelitian Tindakan Kelas (PTK), yang terdiri dari dua siklus. Siklus I menggunakan 2 kali pertemuan tatap muka dan diakhiri dengan penilaian atau Evaluasi. Sedangkan pada siklus II, adapun langkahnya sama dengan siklus I cuma berbeda perlakuan karena di siklus II sub materinya berbeda. Adapun hasil yang didapat dalam pelaksanaan pembelajaran Metode Kooperatif dengan teknik Team Asistead Individualisition (TAI) adalah sebagai berikut: Ketika dilakukan penilaian di Pra Siklus didapat nilai rata-rata siswa : 54,16, kemudian setelah Siklus I terjadi kenaikan nilai rata-rata sebesar: 67,25 dengan tingkat ketuntasan belajar sebanyak $60 \%$. Dan pada saat dilakukan evaluasi pada siklus II nilai ratarata siswa sudah mencapai nilai : 84,5 dengan ketuntasan belajar sebanyak 97,2\%. Sehingga bisa disimpulkan bahwa penggunaan Metode Pembelajaran Metode Kooperatif dengan tehnik Team Asistead Individualisition (TAI), dengan menggunakan dua siklus dapat meningkatkan hasil belajar pada siswa kelas 8-3 SMP Negeri 1 Sumenep dengan materi belajar Tekanan.
\end{abstract}

Kata kunci: Model Pembelajaran Kooperatif tehnik Team Asistead Individualisition (TAI)

\begin{abstract}
Admittedly or not, currently most teachers teach in class more using the lecture method, the reasons given by the teacher why they tend to use the lecture method are easy to implement, besides that another reason is that most students they teach are passive. But is it true that the reason put forward by such a teacher? According to the author's opinion, this is not entirely true, based on experience in the field as education practitioners (teachers), teachers use more lecture methods in teaching because they are poor in other teaching methods, whether it is admitted or not that the government has actually spent a lot of money to educate and train.
\end{abstract}


teachers through education and training (Diklat), workshops, seminars and so on. The goal is one, namely to increase the knowledge and skills of teachers in using learning methods that stimulate students to be active. Creative and innovative. One of the methods introduced to the teacher is the Cooperative Learning Model using the Team Assistant Individualization (TAI) technique. Broadly speaking, this technique is carried out by dividing the class into small groups of about 4 or five people who are selected heterogeneously, then given assistance either individually through the group. The teacher gives the Student Worksheet (LKS), then each group discusses finding the concepts in the $L K S$, after that, each student is given the responsibility to solve the questions in the $L K S$, so this is where the active role of each group member is demanded. This research was conducted at SMP Negeri 1 Sumenep grade 8-3, using a Classroom Action Research (CAR), which consisted of two cycles. Cycle I uses 2 face-to-face meetings and ends with an assessment or evaluation. Whereas in cycle II, the steps are the same as in cycle I, only different treatments because in cycle II the sub-material is different. The results obtained in the implementation of the Cooperative Method learning with the Team Assistance Individualization (TAI) technique are as follows: When the pre-cycle assessment was carried out, the students' average score was obtained: 54.16, then after Cycle I there was an increase in the average value of: 67.25 with a level of learning completeness as much as $60 \%$. And when the evaluation was carried out in cycle II, the students' average score had reached 84.5 with $97.2 \%$ completeness of learning. So it can be concluded that the use of the Cooperative Learning Method with Team Assistance Individualization (TAI) techniques, using two cycles can improve learning outcomes in grade 8-3 students of SMP Negeri 1 Sumenep with Pressure learning material.

\section{Keywords : Cooperative Learning Model Team Assistance Individualization (TAI) technique.}

\section{PENDAHULUAN}

Mata pelajaran IPA bagi siswa termasuk pelajaran yang sulit dipahami, bersama dengan mata pelajaran Matematika dan Bahasa Inggris, beberapa siswa merasa kesulitan menghadapi mata pelajaran tersebut. Penyebabnya adalah mindset yang sudah tertanam di pikiran mereka yang diperoleh melalui kakak kakak kelas mereka dan orang-oirang tua mereka yang menganggap bahwa pelajaran itu memang sulit untuk ditaklukkan, sehingga ada pembenaran manakala mereka mengalami kesulitan untuk memahaminya maka mereka menganggap bahwa hal itu memang wajar karena kakak kelas dan orang tua mereka juga mengalami masalah seperti itu. " Banyak siswa sering sekali berpikir bahwa pelajaran eksak seperti Fisika, Kimia, dan Biologi merupakan pelajaran yang menjadi momok menakutkan, Tim Grasindo ( 2015 : 3 ).

Faktor lain yang membuat siswa kesulitan memahami pelajaran IPA adalah kurannya motivasi belajar murid itu sendiri baik motivasi dari dalam maupun motivasi dari luar dirinya. Motivasi dari dalam semisal; malas, tidak mau bekerja keras, cepat menyerah, tidak punya keinginan kuat dan lain sebagainya. Sedangkan motivasi dari luar meliputi: kurangnya dorongan dari orang tua dan guru, tidak adanya perhatian dari guru, monotonnya cara mengajar guru karena memakai metode itu-itu saja, yang kurang merangsang kreatifitas, inovatif pikiran siswa. Hal ini sejalan dengan pendapat Dr. Hendra Surya ( 2015 : 110 )," Namun tidak sedikit siswa menghadapi dan merasakan bermasalah dengan penamplan, cara mengajar dan sikap guru tertentu, sehingga menimbulkan antipasti, membuat hilang minat belajar dan membuat tak bersemangat siswa untuk mempelajari pelajaran yang diberikan guru tersebut".

Karena itu diperlukan adanya upaya yang dilakukan oleh guru untuk meningkatkan gairah belajar murid melalui model dan tehnik pembelajaran tertentu sehingga motivasi, kreatifitas dan inovatif murid meningkat dengan pesat. Dan ketika motivasi, kreatifitas dan inovatif murid meningkat maka akan berdampak pada keberhasilan peningkatan hasil belajar murid yang berujung pula tercapainya tujuan pendidikan secara umum. Hal ini sejalan dengan pendapat Moh. Zaiful Rosyid,dkk (2019:3), " Kualitas pendidikan sangat berkaitan dengan keberhasilan membentuk siswa yang berkualitas, hal itulah yang menjadi titik pusat dalam Proses belajar mengajar".

Model pembelajaran Kooperatif adalah salah satu model pembelajaran yang menekankan pola kerjasama murid di dalam kelompok, dengan kata lain memecahkan masalah pembelajaran dengan cara bergotong royong. Menurut Aris 
Sohimin dalam Paryanto,S.Pd (2020:3), " Coperative learning merupakan suatu model pembelajaran yang mana peserta didik belajar dalam satu kelompok kelompok kecil yang memiliki tingkat kemampuan yang berbeda". Model ini diyakini bisa memberikan peningkatan motivasi dan pemahaman murid terhadap pelajaran dibandingkan dengan model belajar sendirian. Murid akan lebih termotivasi belajar jika melakukannya bersama-sama dengan temannya, selain itu jika ada permasalahan bisa didiskusikan dengan temannya, dengan kata lain telah terjadi agent of change antara siswa yang pintar kepada siswa yang lemah. Menurut Hariyanto GP. ( 2019 : XIV ), " Dinamika kelompok ini menekankan pada teori teori dan dan proses keterampilannya sehingga hasilnya dapat perubahan perubahan tingkah laku", Disini pula terjadi proses saling melengkapi informasi diantara para murid dalam mengenali sebuah konsep, bagaimanapun juga pemahaman satu konsep oleh beberapa siswa akan lebih baik jika dibandingkan pemahaman konsep oleh satu orang siswa saja.

Karena sifat model pembelajaran Kooperatif bersifat kerjasama maka ada beberapa ciri-ciri yang harus dimiliki pembelajaran ini, yaitu :

1. Setiap anggota saling bergantung satu dengan yang lainnya

2. Adanya tanggung jawab yang harus dipikul setiap anggota agar terjadi keadilan

3. Setiap anggota harus bertatap muka langsung

4. Terjadinya komunikasi yang baik diantara para anggota

Tehnik Team Asistead Individualisition (TAI), adalah salah satu tehnik dari pembelajaran model Kooperatif, menurut Warsono dan Hariyanto dalam Hartina Pratiwi,dkk ( 2019 : 150 ), " Team assisted Individualization (TAI), menggabungkan antara metode pembelajaran kooperatif dengan pengajaran klasikal berbasis individual", tehnik ini lebih menekankan pola kerjasama dan sama kerja, dimana setelah dibentuk kelompok kecil dalam satu kelas yang terdiri dari 4 sampai 5 orang, maka untuk selanjutnya semua anggota kelompok berupaya memahami sebuah konsep materi pembelajaran yang diberikan oleh seorang guru dengan cara diskusi kelompok. Masing-masing kelompok menyampaikan pendapatnya tentang materi dari guru, saling melengkapi, saling mengkritisi dan beragumentasi sampai akhirnya terjadi sebuah kesimpulan konsep. Setelah itu setiap anggota kelompok berbagi tugas menjawab pertanyaan yang diberikan guru melalui Lembar Kerja siswa (LKS). Menurut Sri Lestari (2017:128), " Kerjasama yang terjalin antar peserta didik akan memudahkan siswa di dalam mencapai tujuan pembelajaran".

Pemilihan anggota kelompok dilakukan oleh guru secara heterogen secara kemampuan akademiknya, ini dimaksudkan agar di dalam sebuah kelompok terdapat beberapa siswa pintar, sedang dan kurang. Hal ini dimaksudkan agar terjadi distribusi pengetahuan dari siswa pintar kepada siswa dibawahnya. Jangan sampai dalam satu kelompok terdiri dari siswa pintar semua atau siswa kurang semua, hal ini akan menyebabkan kelompok kurang dinamis. Sehingga yang terjadi kemudian siswa yang pintar membantu siswa yang lemah, sedangkan siswa yang lemah terbantu mendapatkan pemahaman dari siswa yang pintar, inilah sebenarnya kekuatan dari pembelajaran kooperatif tehnik Team Asistead Individualisition (TAI).

Ada beberapa komponen yang harus ada pada Model pembelajaran kooperatif tehnik Team Asistead Individualisition (TAI), yaitu :

a. Tim, artinya kelompok dibentuk sebagai Tim terdiri dari 4 sampai dengan 5 orang murid dengan kemampuan yang heterogen

b. Placement Tes, sebelum kelompok dibuat dilakukan dulu pre tes untuk memetakan kemampuan siswa yaitu kelebihan dan kekurangan siswa pada mata pelajaran apa

c. Student creatife, menanamkan mindsite dalam diri siswa bahwa keberhasilah kelompok lebih utama dari keberhasilan diri karena ini adalah sebuah Tim. Ibarat sepakbola hasil akhir tim yang menentukan kemenangan bukan keberhasilan individu

d. Team Study, yaitu tahapan belajar yang harus dilalui oleh kelompok, disini peran guru memberikan langkah-langkah yang harus dilakukan oleh murid 
dalam sebuah kelompok agar dapat memahami konsep belajar yang diinginkan.

e. Team score and Team recognition, disini guru memberikan nilai sebagai reward bagi Tim yang berhasil dengan baik dan memberikan motivasi bagi Tim yang kurang berhasil untuk berjuang lebih keras lagi.

f. Teaching Group, pemberian materi singkat oleh guru menjelang pembenahan tugas kelompok

g. Fact Tes, dilaksanakan tes kecil berdasarkan fakta-fakta yang ditemukan oleh murid

h. Whole Class Unit, pemberian materi kembali oleh guru sebagai strategi pemecahan masalah.

Agar model pembelajaran Kooperatif tehnik Team Asistead Individualisition (TAI) bisa berjalan dengan efektif, maka diperlukan beberapa langkah yang harus ditempuh, yaitu:

1. Tahap persiapan, dalam tahap ini yang harus dilakukan adalah :

a. Menetapkan tujuan pembelajaran, berdasarkan tujuan umum dan tujuan instruksional khusus

b. Menetapkan Topik pembelajaran, menentukan topik yang akan dibahas

c. Mengumpulkan materi ajar, berasal dari buku materi guru, internet, dan bahan ajar lainnya

d. Merencanakan kelompok kecil yang terdiri dari 4 sampai dengan 5 orang murid, dibuat heterogen secara kemampuan

2. Tahap pelaksanaan

a. Merealisasikan pembentukan kelompok kecil

b. Sosialisasi tujuan kegiatan ini

c. Menjelaskan materi secara singkat

d. Menjelaskan tugas-tugas yang harus dilakukan pada setiap kelompok

3. Tahap Evaluasi

a. Mengobservasi jalannya kegiatan diskusi

b. Mempersilahkan ketua kelompok mempresentasikan hasil diskusinya

4. Meminta murid membuat dan mengumpulkan laporan

a. Meminta setiap kelompok membuat laporan kegiatannya secara tertulis

b. Mengumpulkan hasil kegiatan kelompok

Salah satu tujuan Penelitian Tindakan Kelas ini adalah adanya kolaborasi antara Peneliti dengan guru pengajar atau praktisi pendidikan, untuk melakukan identifikasi permaslahan yang dialami oleh guru di dalam melaksanakan pembelajaran di kelas. Kemudian setelah teridentifikasi dengan baik kendala-kendala yang terjadi di kelas yang menyebabkan tujuan pembelajaran tidak tercapai dengan baik, maka selanjutnya dicarikan solusi terhadap permasalahn tersebut.

Semua kegiatan yang dilakukan diobservasi dan didokumentasikan dengan baik, untuk memudahkan penelitian ini dilakukan maka digunakanlah tahapan-tahapan penelitian dengan menggunakan siklus Penelitian Tindakan Kelas, yang meliputi : Perencanaan, Pelaksanaan, Observasi dan refleksi. Direncanakan penelitian ini akan dilaksanakan 3 siklus, namun memasuki siklus yang ke 2, sudah tampak keberhasilan penggunaan model pembelajaran kooperatif tehnik Team Asistead Individualisition (TAI), maka peneliti memandang sudah cukup sampai siklus 2 saja.

Berdasarkan hasil pengamatan (Observasi), di dapat kondisi faktual dimana prestasi belajar murid untuk mata pelajaran IPA kebanyakan rendah, melalui wawancara yang peneliti lakukan dengan beberapa murid, untuk menanyakan mengapa prestasi mereka rendah, di dapat jawaban; bahwa pelajaran IPA yang mereka ikuti sangat sulit di mengerti, selain itu mereka merasa bosan mengikuti pelajaran IPA karena metode mengajar gurunya menggunakan metode ceramah saja, sehingga ada perasaan jenuh di pikiran mereka, sehingga hal ini berimbas kepada hasil belajar mereka yang rendah. Tentu ini sangat bertentangan dengan prinsip belajar IPA yang menuntut murid untuk berpikir kritis sekaligus juga kreatif. Model pembelajaran yang selama ini dilakukan kuran memberikan ruang untuk berpikir kritis 
dan kreatid pada murid. Mereka lebih banyak mencernah ceramah dari guru, sesekali menjawab pertanyaan yang diajukan oleh guru. Hasil wawancara dengan guru mata pelajaran memang mengakui bahwa sebagian besar pembelajaran yang dilakukan menggunakan model pembelajaran ceramah.

Untuk menguatkan data, peneliti melakukan Tes sebelum dilakukan penelitian ini atau Pre Tes, ternyata hasilnya rata-rata pencapaian tesnya adalah 54,16 dengan tingkat ketuntasan hanya 38,8\%, hasil ini berada jauh dibawah ketuntasan minimal di sekolah tersebut untuk mata pelajaran IPA yaitu $61 \%$. Maka mau tidak mau kondisi seperti ini harus di perbaiki, tidak boleh hal seperti ini berjalan terus tanpa ada solusi untuk meningkatkan hasil belajar siswa.

Setelah dilakukan koordinasi dengan guru mata pelajaran, maka diputuskan untuk melakukan perubahan yang bersifat inovatif dengan mengganti metode ceramah yang selama ini digunakan dengan melakukan pembelajaran model Kooperatid dengan tehnik Team Asistead Individualisition (TAI), sekaligus juga diteliti tingkat keberhasilannya dengan menggunakan model penelitian Penelitian Tindakan Kelas atau juga dikenal dengan istilah Action Reserche. Haelaludin dan Hengki Wijaya ( 2019 : 46 ), mengatakan: "Action research memiliki orientasi kolaborasi dan perubahan yang melibatkan peneliti dan subjek penelitiannya".

Kelas yang dijadikan subjek penelitian adalah kelas 8-3 SMP Negeri 1 Sumenep, pertimbangan pemilihan kelas ini dijadikan subjek penelitian selain karena tempat mengajar peneliti juga karena di kelas ini muridnya kemampuannya sangat heterogen, dalam arti ada yang pintar, sedang maupun kurang, sehingga ini menjadi pertimbangan yang sangat cocok untuk menerapkan tehnik Team Asistead Individualisition (TAI).

Maka selanjutnya dimulailah persiapan melakukan penerapan tehnik Team Asistead Individualisition (TAI) sekaligus melakukan penelitian terhadap prosesnya. Materi pembelajaran yang diambil dalam penelitian ini adalah topik: Tekanan, kenapa topik ini yang dipilih? Karena berdasarkan masukan dari beberapa guru rekan peneliti serta keluhan siswa, bahwa materi adalah materi yang sulit dicerna. Oleh karena itu peneliti merasa tertantang untuk melakukan penelitian dengan topik Tekanan ini.

Tehnik Team Asistead Individualisition (TAI) ini adalah gabungan belajar secara individu dengan belajar kelompok. Karena itu peneliti berharap ada hasil yang positip yang bisa dicapai dengan penggunaan tehnik Team Asistead Individualisition (TAI), selain adanya peningkatan prestasi hasil belajar, penulis juga berharap ada perasaan senang, nyaman dan termotivasi dari siswa di dalam mengikuti pembelajaran dengan tehnik Team Asistead Individualisition (TAI) ini. Karena itu peneliti ingin melakukan kajian penelitian, Penerapan Model Pembelajaran Kooperatif dengan Tehnik Team Asistead Individualisition (TAI) untuk meningkatkan hasil belajar siswa pada mata pelajaran IPA dengan materi Ajar Tekanan di Kelas 8-3 SMP Negeri 1 Sumenep semester 2 TP. 2015/2016.

\section{METODE}

Penelitian ini dilaksanakan pada kelas 8-3 SMP Negeri 1 Sumenep di semester 2 Tahun pelajaran 2015/2016, adapun jenis penelitian yang digunakan adalah jenis Penelitian Tindakan atau Action Researche. Adapun Penelitian Tindakan Kelas (PTK) ini mengacu pada pendapat Nurdinah Hanifah (2014:1), "Penelitian Tindakan Kelas dilaksanakan sebagai Upaya meningkatkan efisiensi dan Kualitas Pendidikan terutama proses dan hasil belajar siswa terutama pada level kelas". Adapun subjek penelitian ini adalah semua murid kelas 8-3 SMP Negeri 1 Sumenep sebanyak 48 orang, dengan tujuan meningkatkan pencapaian hasil belajar siswa pada mata pelajaran IPA dengan materi: Tekanan. Dalam penelitian ini, peneliti berkolaborasi dengan teman teman sejawat penulis sesama guru IPA yaitu Ibu Rubini,S.Pd.

Menurut Muhamad Anugrah,S.PdI.S.Sos.M.Pd, (2019 : 19 ), "Penelitian tindakan kelas merupakan salah satu karya publikasi ilmiah dalam konteks pengembangan keprofesian guru (PKB)", tahapan Penelitian Tindakan Kelas, meliputi 
: Plan (Perencanaan); Action (Tindakan); Observation (Pengamatan); Reflektion (Refleksi). Oleh karena itu dalam penelitian peneliti menggunakan empat tahapan dalam setiap siklusnya. Awalnya peneliti merencanakan akan melaksanakan penelitian ini menjadi tiga siklus, namun dalam pelaksanaannya setelah melalui siklus I dan siklus II, sudah menunjukkan hasil yang sangat bagus maka peneliti tidak merasa perlu untuk melanjutkan ke siklus III.

Selanjutnya dalam artikel ini peneliti akan sajikan, tahapan-tahapan pelaksanaan penelitian ini, agar diperoleh gambaran menyeluruh bagaimana sebenarnya penelitian ini dilaksanakan, adapun tahapannya adalah sebagai berikut:

1. Pra Siklus

Pada tahap ini peneliti dan kolaboran melakukan Tes awal dengan materi tes pelajaran sebelumnya tentang Topik pembelajaran Tekanan. Hal ini sejalan dengan pendapat Sri Esti W Djiwandono ( 1989 : 412 ), yang mengatakan : " Tes Hasil Belajar dilakukan untuk mengetahui hasil yang telah dicapai oleh suatu bentuk pengajaran". Disini peneliti ingin mengetahui seberapa besar hasil belajar yang diperoleh oleh murid pada pembelajaran sebelumnya. Tes yang dibuat standar mengacu kepada kisi-kisi soal serta indikator soal yang dibuat oleh guru. Tujuan kegiatan ini adalah agar diperoleh data yang benar-benar objektif mengenai hasil belajar siswa setelah memperoleh pembelajaran dari guru. Ini sangat penting dilakukan untuk membandingkan keberhasilan pembelajaran sebelumnya dengan pembelajaran yang akan di lakukan setelah ini, sehingga peneliti bisa mengambil kesimpulan nantinya apakah Model belajar Kooperatif dengan tehnik Team Asistead Individualisition (TAI) menunjukkan hasil atau tidak. Menurut Afi Parnawi ( 2020 : 11 ), "Komponen pokok dalam penelitian tindakan Kurt Lewis, adalah : Plan (Perencanaan), Tindakan (Acting), Observasing ( Pengamatan ), Refleksi (Reflecting)".

2. Siklus I

Dalam siklus I ini, peneliti bersama kolaboran melakukan langkah-langkah sesuai tahapan Penelitian Tindakan Kelas, yaitu

a. Perencanaan

Yang dilakukan oleh peneliti bersama kolaboran pada tahapan persiapan ini adalah mempersiapkan segala sesuatunya, yaitu : Silabus, RPP, LKS, serta materi ajarnya. Menurut Prof.Dr. H. Wina Sanjaya,M.Pd. ( 2016 : 16 ),"Pemeran utama PTK adalah guru itu sendiri, karena PTK berangkat dari permasalahan yang dihadapi oleh guru dalam proses pembelajaran yang dilakukannya bersama siswa". Selain itu yang tidak kalah pentingnya dipersiapkan juga instrumen yang digunakan melakukan observasi, seperti : Pedoman wawancara, pedoman observasi dan lain sebagainya.

b. Pelaksanaan

Secara garis besar pada tahapan pelaksanaan ini guru yang sekaligus kolaboran peneliti melakukan pembelajaran Model belajar Kooperatif dengan tehnik Team Asistead Individualisition (TAI). Lebih rinci tentang apa yang dilakukan oleh guru pada kesempatan ini adalah sebagai berikut :

1) Menyapa siswa dengan salam sambil menanyakan kabar siswa serta siapa saja yang berhalangan hadir hari itu.

2) Melakukan Appersepsi yaitu mulai menghubungkan materi yang akan disampaikan dengan pengalaman hidup murid sehari-hari. Karena materinya tentang tekanan maka guru bercerita tentang sesuatu yang mengakibatkan proses tekanan dalam kehidupan sehari-hari siswa.

3) Guru memulai pertanyaan sederhana kepada murid, "Pernakah kamu perhatikan benda yang ada di dalam air terasa ringan?". Yang dijawab kompak oleh siswa "pernah". Pancingan pertanyaan itu kemudian berkembang menjadi tanya jawab, secara bergantian antara guru dengan murid.

4) Kemudian guru memberi kesempatan kepada murid untuk bertanya seluas-luasnya, murid sangat antusias menanyakan kepada guru. 
Sekali-sekali guru juga bertanya kepada murid, dengan maksud untuk mengeksplore pemahaman mereka tentang konsep Tekanan

5) Setelah cukup lama terjadi tanya jawab yang aktif antara guru dan murid, maka selanjutnya guru membagi siswa kedalam kelompok kecil, setiap kelompok beranggotakan 5 orang. Pemilihan anggota kelompok ditentukan oleh guru secara heterogen berdasarkan hasil penilaian Pre Tes diawal kegiatan.

6) Setelah terbentuk kelompok maka, guru membagikan LKS kepada setiap kelompok, dan meminta ketua kelompok untuk secara adil membagi tugas LKS itu pada setiap kelompok.

7) Guru membimbing siswa dalam kelompok yang bertanya tentang materi yang ada di LKS itu dengan sabar

8) Setelah selesai maka LKS itu dikumpulkan oleh guru, secara acak guru meminta setiap kelompok untuk mempresentasikan hasil pengisian LKS itu di depan semua murid yang lain, tidak lupa diberikan reward berupa pujian jika benar, dan motivasi manakala ada jawaban yang kurang.

9) Setelah selesai guru menjelaskan tambahan materi serta menyimpulkan hasil kegiatan hari itu.

10) Mempersilahkan murid kembali ke tempat duduknya

11) Memberikan Tes, sebagai bahan evaluasi keberhasilan pelaksanaan kegiatan.

c. Observasi

Menurut Pinton Setya Mustafa,dkk ( 2000 : 89 ), "Instrumen observasi digunakan dalam penelitian kualitatif sebagai pelengkap dari teknik wawancara yang telah dilakukan. Observasi dalam penelitian kualitatif digunakan untuk melihat dan mengamati secara langsung objek penelitian", Pada tahapan ini peneliti aktif melakukan pengamatan serta mencatat hasil pengamatannya dengan cermat. Hal-hal yang diamati adalah : bagaimana guru melaksanakan pembelajaran itu dengan Model belajar Kooperatif dengan tehnik Team Asistead Individualisition (TAI), sikap dan respon siswa pada saat mengikuti proses belajar mengajar, hasil tes dari murid setelah mengikuti pembelajaran.

d. Refleksi

Menurut Adi suprayitno ( 2020 : 129 ), "Proses refleksi ini memegang peran yang sangat penting dalam menentukan suatu keberhasilan PTK. Dengan suatu refleksi yang tajam dan terpercaya akan didapat suatu masukan yang sangat berharga dan akurat bagi penentuan langkah ...". Pada tahapan ini ada beberapa hal yng dilakukan oleh peneliti, yaitu :

a) Melakukan analisa terhadap hasil observasi yang sudah dilakukan pada tahapan sebelumnya, pada tahap ini peneliti bersama-sama kolaboran mencoba menganalisis proses pembelajaran yang telah dilakukan apakah sudah sesuai dengan scenario yang dibuat atau tidak, selain ini menganalisis juga respon dari murid terhadap penyajian pembelajaran model ini serta menganalisis hasil tes yang dilakukan pada akhir pembelajaran.

b) Melakukan diskusi terhadap hasil analisis untuk keperluan tindak lanjut yang harus dilakukan pada siklus berikutnya. Disini peneliti melakukan tukar pikiran dengan kolaboran, adakah kekurangan yang harus diperbaiki untuk pelaksanaan siklus II.

3. Siklus II

Siklus II ini adalah lanjutan dari siklus I, dimana peneliti dan kolaboran memandang perlu untuk melanjutkannya karena dirasa hasil yang diharapkan masih dibawah ekspektasi. Selain itu dalam siklus II ini dilakukan perbaikan-perbaikan kekurangan yang terjadi pada siklus I, mengenai tahapannya masih sama, yaitu :

a) Perencanaan

Menurut Prof. Dr.H. Wina Sanjaya,M.Pd. ( 2016:67), "Pelaksanaan tindakan tanpa rencana, tindakan itu tidak akan terarah. Oleh karena itu, tindakan dalam 
pelaksanaan PTK akan sangat tergantung pada perencanaan yang disusun". Yang dilakukan oleh peneliti bersama kolaboran pada tahapan persiapan ini adalah masih mempersiapkan segala sesuatunya, yaitu : Silabus, RPP, LKS, serta materi ajarnya. Selain itu yang tidak kalah pentingnya dipersiapkan juga instrumen yang digunakan melakukan observasi, seperti : Pedoman wawancara , pedoman observasi dan lain sebagainya.

b) Pelaksanaan

Pelaksanaan kegiatan pada siklus II ini tahapannya masih sama dengan siklus II, guru yang sekaligus kolaboran peneliti melakukan pembelajaran Model belajar Kooperatif dengan tehnik Team Asistead Individualisition (TAI). Lebih rinci tentang apa yang dilakukan oleh guru pada kesempatan ini adalah sebagai berikut :

1) Guru menyapa siswa dengan salam sambil menanyakan kabar siswa serta siapa saja yang berhalangan hadir hari itu.

2) Melakukan Appersepsi yaitu mulai dengan mengigatkan kesimpulan yang didapat pada pertemuan sebelumnya.

3) Guru memulai dengan mengaitkan gejala-gejala yang terjadi di alam ini dengan teori tekanan.

4) Guru mulai mengeluarkan alat dari Laboratorium dan mulai mempraktekkan konsep benda timbul tenggelam di air

5) Memberi kesempatan pada murid untuk bertanya, kemudian guru juga melontarkan beberapa pertanyaan untuk mengeksplorasi kemampuan siswa.

6) Membagi siswa kedalam kelompok kecil, setiap kelompok beranggotakan 5 orang. Pemilihan anggota kelompok ditentukan oleh guru secara heterogen berdasarkan hasil penilaian Pre Tes diawal kegiatan.

7) Setelah terbentuk kelompok maka, guru membagikan LKS kepada setiap kelompok, dan meminta ketua kelompok untuk secara adil membagi tugas LKS itu pada setiap kelompok.

8) Guru membimbing siswa dalam kelompok yang bertanya tentang materi yang ada di LKS itu dengan sabar

9) Setelah selesai maka LKS itu dikumpulkan oleh guru, secara acak guru meminta setiap kelompok untuk mempresentasikan hasil pengisian LKS itu di depan semua murid yang lain, tidak lupa diberikan reward berupa pujian jika benar, dan motivasi manakala ada jawaban yang kurang.

10) Setelah selesai guru menjelaskan tambahan materi serta menyimpulkan hasil kegiatan hari itu.

11) Mempersilahkan murid kembali ke tempat duduknya

12) Memberikan Tes, sebagai bahan evaluasi keberhasilan pelaksanaan kegiatan.

c) Observasi

Pada tahapan ini peneliti aktif melakukan pengamatan serta mencatat hasil pengamatannya dengan cermat. Hal-hal yang diamati adalah : bagaimana guru melaksanakan pembelajaran itu dengan Model belajar Kooperatif dengan tehnik Team Asistead Individualisition (TAI), sikap dan respon siswa pada saat mengikuti proses belajar mengajar, hasil tes dari murid setelah mengikuti pembelajaran.

d) Refleksi

Menurut Taufiqur Rahman,S.Pd. M.PdI. ( 2018 : 14 ), "Proses refleksi ini memegang peran yang sangat penting dalam menentukan suatu keberhasilan PTK. Dengan suatu refleksi yang tajam dan terpercaya akan didapat suatu masukan yang sangat berharga dan akurat bagi penentuan langkah ...". Pada tahapan ini ada beberapa hal yng dilakukan oleh peneliti, yaitu :

1) Melakukan analisa terhadap hasil observasi yang sudah dilakukan pada tahapan sebelumnya, pada tahap ini peneliti bersama-sama kolaboran mencoba menganalisis proses pembelajaran yang telah dilakukan apakah sudah sesuai dengan scenario yang dibuat atau tidak, selain ini menganalisis 
juga respon dari murid terhadap penyajian pembelajaran model ini serta menganalisis hasil tes yang dilakukan pada akhir pembelajaran.

2) Melakukan diskusi terhadap hasil analisis untuk keperluan tindak lanjut yang harus dilakukan pada siklus berikutnya. Disini peneliti melakukan tukar pikiran dengan kolaboran, adakah kekurangan yang harus diperbaiki untuk pelaksanaan siklus II.

Metode pengumpulan data yang digunakan dalam penelitian ini secara garis besar ada 3 , yaitu:

1. Metode Observasi

, Prof. Dr. Conny R Semiawan, dalam Menurut Dr. JR. Raco,ME,MSc ( 2019 : 122

), " Observasi adalah bagian dari pengumpulan data, Observasi berarti mengumpulkan data secara langsung di lapangan Observasi bermakna mengamati, oleh karena itu dalam penelitian ini peneliti melakukan pengamatan atau obserasi untuk mendapatkan data yang objektif mengenai pelaksanaan Model belajar Kooperatif dengan tehnik Team Asistead Individualisition (TAI), hal-hal yang diamati adalah keseluruhan proses mulai dari perencanaan sampai pelaksanaan. Informasi detail mengenai proses kegiatan ini menjadi dasar evaluasi apakah Model belajar Kooperatif dengan tehnik Team Asistead Individualisition (TAI), terlaksana dengan baik atau tidak. Serta apa yang menyebabkan kegiatan ini tidak berhasil, semuanya dicatat secara detail oleh peneliti.

2. Metode Dokumentasi

Alminiati ( 2008 : 170 ), mengatakan, "Dokumentasi merupakan metode pengumpulan data dengan jalan menyelidiki dokumen - dokumen yang sudah ada dan merupakan tempat menyimpan sejumlah data maupun informasi". Penggunaan metode Dokumentasi dalam kegiatan ini, lebih kepada dokumentasi yang bersifat paper. Artinya data siswa yang terdokumentasi kemudian dianalisis. Dalam penelitian ini data dokumen yang digunakan adalah dokumen hasil tes, mulai dari Pre Tes, Tes setelah siklus I, Tes setelah siklus II.

3. Metode Tes

Tes yang digunakan adalah Tes hasil kegiatan belajar, bentuk tesnya adalah objektif atau pilihan ganda. Tes ini sudah disesuaikan dengan kisi-kisi dan indicator yang dibuat oleh guru. Tes yang dilakukan pada Model belajar Kooperatif dengan tehnik Team Asistead Individualisition (TAI), sebanyak 3 kali. Tes pertama saat Pretes, masudnya sebelum kegiatan Model belajar Kooperatif dengan tehnik Team Asistead Individualisition (TAI) dilakukan, kemudian tes kedua setelah pelaksanaan Siklus I dan yang ketiga pada saat selesai Siklus II.

Adapun rumusan penilaian untuk menentukan hasil dari tes objek tersebut, dibuat rumusan sebagai berikut:

$$
S=\frac{R}{B} \times 100 \%
$$

Keterangan :

$\mathrm{S}=$ Skor terakhir atau skor yang diharapkan

$\mathrm{B}=$ Jumlah soal keseluruhan

$\mathrm{R}=$ Jumlah soal yang dijawab betul

\section{HASIL DAN PEMBAHASAN}

Model belajar Kooperatif dengan tehnik Team Asistead Individualisition (TAI), adalah suatu model pembe!ajaran yang didasarkan atas diskusi yang di la kukan dalam kelompok tetapi tidak meninggalkan metode pendamping secara individu. Metode sangat simple dilaksanakan, prinsipnya memberikan tanggung jawab kepada siswa bersama-sama kelompoknya untuk menemukan konsep belajar sendiri, namun demikian tidak berarti mengesampingkan peranan guru. Sebab guru juga masih sangat berperan di dalam melayani dinamika pembentukan konsep belajar dari 
murid, guru meluruskan jika konsepnya melenceng, guru juga sebagai tempat bertanya bagi siswa manakalah mereka bertanya. Model belajar Kooperatif dengan tehnik Team Asistead Individualisition (TAI), diyakini dapat meningkatkan motivasi belajar murid, sebab tehnik ini dilakukan menggunakan kelompok kecil di kelas, pembelajaran yang dilakukan dengan diskusi bersama teman sebaya akan menghasilkan perasaan senang, bersemangat dan tanpa tekanan. Sehingga bisa disimpulkan Pelaksanaan Model belajar Kooperatif dengan tehnik Team Asistead Individualisition (TAI), dapat meningkatkan hasil belajar siswa kelas 8-3 SMP Negeri 1 Sumenep, semester genap Tahun Pelajaran 2015/2016. Menurut Dr. H. Mohammad Holis, M.Si ( 2016 : 179 ), " Metode ini banyak nilai positip dan pesan moral bagi anak didik, antara lain melatih peserta didik untuk bertanggung jawab terhadap tugas yang menjadi tanggung jawabnya, melatih berkomunikasi dimulai dari kelompok, mengasah kepercayaan dirinya, peserta didik dapat belajar untuk menang sendiri (egois) dan berlatih bekerjasama".

Hasil daripada pelaksanaan Model belajar Kooperatif dengan tehnik Team Asistead Individualisition (TAI), dapatlah penulis gambarkan dalam narasi berikut. Bahwa pada saat dilaksanan Siklus I, penerapan Model belajar Kooperatif dengan tehnik Team Asistead Individualisition (TAI), dirasa belum maksimal. Dari hasil observasi oleh peneliti didapat fakta tentang aktifitas siswa, tercatat siswa yang sangat aktif mengikuti alur kegiatan ini sebanyak 17,5\%; aktif sebanyak 48,7\% dan yang cukup aktif sebanyak 38,7\%. Sehingga bisa dibilang belum masuk ke indicator berhasil. Adapun aspek aktifitas yang diamati peneliti meliputi: antusias murid dalam mengikuti PBM, aktifitas di dalam menjawab pertanyaan guru, aktifitas mengemukakan ide atau gagasan dan antusiasnya dalam bertanya kepada guru. Namun demikian ada peningkatan hasil belajar, dari hasil tes yang dilakukan menunjukkan bahwa rata-rata hasil belajar siswa mencapai skor 67,25, hal ini sudah berada diatas KKM sekolah ini yang hanya 61 untuk mata pelajaran IPA, namun demikian siswa yang mencapai ketuntasan sesuai KKM hanya berkisar $60 \%$, ini tentu masih peneliti anggap kurang, adapun target ketuntasan siswa yang diharapkan peneliti adalah diatas $75 \%$. Dari hasil evaluasi yang dilakukan ditemukan factor penyebabnya, yaitu kurangnya pemahaman murid tentang langkah-langkah penggunaan Model belajar Kooperatif dengan tehnik Team Asistead Individualisition (TAI), sehingga berakibat kurangnya tanggung jawab anggota kelompok. Selain itu pembagian kelompok dirasa masih belum maksimal, sebaran siswa yang pintar, sedang dan lemah dalam satu kelompok tidak maksimal, dalam arti masih ada kelompok yang dominan anak pintarnya, atau kelompok yang dominan siswa lemahnya. Untuk itu peneliti bersama kolaboran bertekad melanjutkan penelitian ke siklus II, tentu saja dengan beberapa perbaikan mendasar yang ditemukan pada kesalahan di siklus I.

Pada siklus II, guru bersama peneliti mulai sedikit merubah strategi untuk merangsang murid agar bisa lebih aktif melaksanakan pembelajaran sebagai tindak dari evaluasi yang dilakukan pada siklus I, strategi yang dimaksud dengan memberikan kesempatan terlebih dahulu pada murid untuk membaca materi terlebih dahulu, setelah selesai setiap murid diminta mempersiapkan pertanyaan terkait materi yang telah dibacanya. Ternyata strategi ini cukup ampuh, murid menjadi antusias mengajukan pertanyaan, guru cukup menjelaskan atas pertanyaan yang diajukan murid, setelah itu guru menjelaskan dengan gamblang aturan main pengisian LKS yang akan diberikan kepada setiap kelompok, yang intinya meminta semua anggota untuk mengisi LKS yang diberikan sesuai dengan pembagian tugas yang diatur oleh ketua kelompok, jadi semua siswa harus aktif berpartisipas. Hasilnya memang sudah kelihatan, hasil pengamatan peneliti, 48,7\% siswa sangat aktif, $38,7 \%$ murid mencapai kriteria aktif serta hanya $17,5 \%$ murid dengan kriteria cukup aktif. Hasil pembelajaran juga menunjukkan peningkatan yang signifikan pada siklus II ini, rata-rata capaian nilai hasil belajar adalah: 84,5 dengan ketuntasan belajar 97,5\%. Menurut Khairun nisya ( 2019 : 167 ), "Indikator Kinerja Pada bagaian Indikator kinerja ini tolak ukur keberhasilan tindakan perbaikan yang akan dipakai, ditetapkan eksplisit sehingga memudahkan verifikasinya untuk tindak perbaikan 
melalui PTK". Dengan pencapaian hasil sedemikian maka peneliti mengambil kesimpulan bahwa Model belajar Kooperatif dengan tehnik Team Asistead Individualisition (TAI), sudah cukup berhasil meningkatkan aktifitas siswa di dalam mengikuti pembelajaran IPA dengan materi Tekanan, serta meningkatkan nilai hasil belajarnya dengan sangat pesat, maka penulis berasumsi tidak perlu melanjutkan ke Siklus II.

Untuk lebih memberikan gambaran tentang hasil pelaksanaan Model belajar Kooperatif dengan tehnik Team Asistead Individualisition (TAI), di Kelas 8-3 SMP Negeri 1 Sumenep, penulis menyajikannya dalam bentuk tabel di bawak ini :

Tabel 1. Keaktifan siswa di dalam mengikuti Pembelajaran

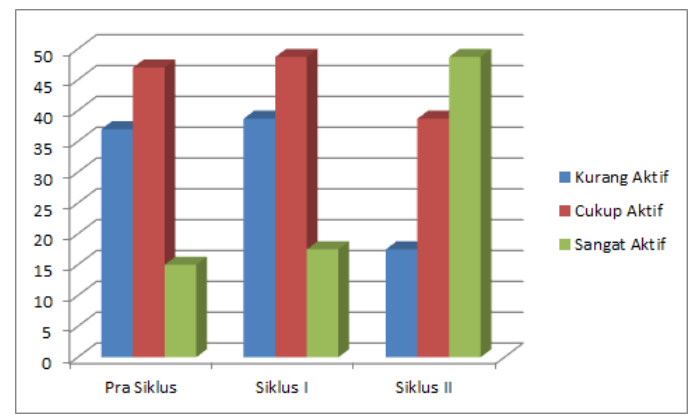

Disini terlihat perbedaan yang nyata diantara Pra siklus, siklus I dan siklus II, keaktifan siswa yang dapat diukur pada saat pra siklus yang Kurang aktif mencapai $37 \%$ lalu meningkat di siklus I $38,7 \%$ dan turun $17,5 \%$ di siklus II, sedangkan aktifitas murid dengan kategori cukup di pra siklus hanya $47 \%$ menigkat menjadi $48,7 \%$ di siklus I dan turun menjadi $38,7 \%$ di siklus II. Sementara aktifitas murid dengan kategori sangat aktif di pra siklus $15 \%$ lalu meningkat di siklus I menjadi $38,7 \%$ serta meningkat lagi di siklus II menjadi $48,7 \%$

Tabel 2. Hasil Belajar Siswa

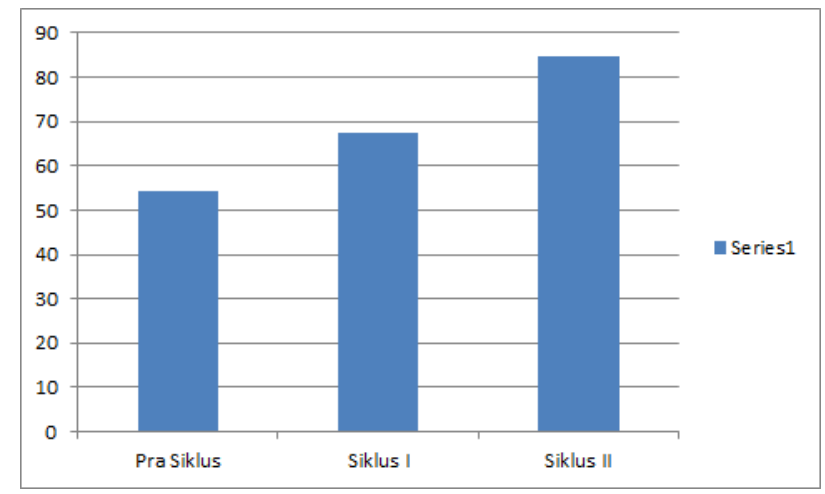

Di dalam table ini menunjukkan rata-rata perolehan nilai murid sejak pra siklus, siklus I maupun siklus II. Nampak saat sebelum dilakukan Model belajar Kooperatif dengan tehnik Team Asistead Individualisition (TAI) atau Pra siklus nilai rata-rata siswa hanya mencapai 54,16, lalu meningkat saat selesai siklus I menjadi 67,25 dan meningkat lagi di saat selesai mengikuti siklus II menjadi 86,3 .

\section{KESIMPULAN}

Berdasarkan paparan hasil diatas, maka penulis dapat mengambil kesimpulan bahwa Model belajar Kooperatif dengan tehnik Team Asistead Individualisition (TAI), yang dilaksanakan pada kelas 8-3 SMP Negeri 1 Sumenep di semester genap Tahun Pelajaran 1995/1996, yaitu : 
1. Model belajar Kooperatif dengan tehnik Team Asistead Individualisition (TAI), dapat dilaksanakan dengan baik di SMP Negeri 1 Sumenep

2. Penerapan Model belajar Kooperatif dengan tehnik Team Asistead Individualisition (TAI) dapat meningkatkan hasil belajar siswa.

3. Simpulan ini bersifat kondisonal, artinya berhasil diterapkan di SMP Negeri 1 Sumenep tapi belum tentu berhasil diterapkan di sekolah lain.

\section{SARAN}

Ada beberapa saran yang dapat disampaikan peneliti berdasarkan hasil yang diperoleh pada Model belajar Kooperatif dengan tehnik Team Asistead Individualisition (TAI), yaitu :

1. Penerapan Model belajar Kooperatif dengan tehnik Team Asistead Individualisition (TAI), bisa menjadi bahan renungan bagi guru untuk meningkatkan profesinalitasnya.

2. Penerapan Model belajar Kooperatif dengan tehnik Team Asistead Individualisition (TAI), bisa menjadi motivasi bagi guru untuk melakukan hal yang sama bahkan mengembangkannya dengan model dan tehnik pembelajaran yang lain.

3. Sekolah bisa memberikan kesempatan yang seluas-luasnya kepada guru untuk melakukan inovasi pembelajaran.

\section{REFERENSI}

Adi Suprayitno,M.Pd. Menyusun PTK Era 4.0. 2020. Deepublish Publisher. Jakarta.

Afi Parnawi,M.Pd,Dr. Penelitian Tindakan Kelas (Classroom Action Researche). 2020. Deepublish Publisher. Jakarta.

Alminiati, Paradigma baru Pembelajaran Keagamaan di Madrasah Ibtidaiyah. 2008. Gramedia. Jakarta.

H. Wino Sanjaya,M.Pd,Dr. Penelitian Tindakan Kelas. 2016. Gramedia. Jakarta

Hariyanto GP, Biblical Hebrew : An Introductory Syntax and Gramatical. 2019. Agia Media. Bandung

Hartini Pratiwi. Prosiding Seminar Nasional Pendidikan Matematika II (SNPMAT II), Pembelajaran Matematikan dalam Era Revolusi Industri 4.0. 2019. Gramedia. Jakarta

Hendra Surya,Dr. Cara Cerdas (Smart) Mengatasi Kesulitan Belajar. 2015. PT Elex Media Komputindo. Jakarta.

Helaludin;Hengki Wijaya. Analisis Data Kualitatif; Sebuah Tinjauan Teori dan Praktek. 2019. Gramedia. Jakarta.

H. Mohammad Holis,M.Si,Dr. 62 Rekayasa Guru dalam Pembelajaran (Fenomena Merdeka Belajar dan Moderasi Beragama pada Madrasah. 2020. CV. Jakad Media Publishing. Surabaya.

H. Wina Sanjaya,M.Pd. Prof. Dr. Penelitian Tindakan Kelas. 2016. Gramedia. Jakarta.

JR. Raco,ME, M.Sc,Dr. Metode penelitian Kualitatif, Jenis, Karakteristik dan Keunggulannya. 2019. Gramedia. Jakarta.

Khairun Nisya. PTK Jadikan Guru Profesional. 2019. Guepedia. Jakarta. 
Moh. Zaiful Rosyid,dkk. Prestasi Belajar. 2019. Literasi Nusantara. Batu

Muhamad Anugrah,S.PdI,S.Sos.M.Pd, Penelitian Tindakan Kelas. 2016. Gramedia. Jakarta

Paryanto,S.Pd. Implementasi Model Pembelajaran Kooperatif Tipe STAD (Student Teams Achievment Division) untuk Pelajaran Passing alam Permainan Bola Voli. 2020. AhliMedia Press. Malang.

Pinton Setya Mustafa,dkk. Metode Penelitian Kuantitatif, Kualitatif dan Penelitian Tindakan Kelas dalam Pendidikan Olahraga. 2020. Universitas Negeri Malang. Malang.

Sri Esti W Djiiwandono. Psikologi Pendidikan. 1989. PT Grasindo. Jakarta.

Sri Lestari.Upaya Meningkatkan Kerjasama dan Prestasi Belajar dengan Model Pembelajaran Team Asistead Individualization (TAI) dibantu media LKS pada Materi Stoikiometri di Kelas X MIPA 1 Semester Genap SMA Negeri 6 Surakarta. TP 2016/2017. 2017. Jurnal Pendidikan Empirisme.

Taufiqur Rahman,S.Pd.M.PdII. Aplikasi Model model Pembelajaran dalam Penelitian Tindakan Kelas. 2018. CV Pilar Nusantara. Semarang.

Tim Grasindo, Sikat Habis Teori dan Rumus IPA; IImu Pengetahuan Alam. 2015. PT Gracindo. Jakarta. 